\title{
The Legacy of Hermes: Deception and Dialectic in Plato's Cratylus
}

Olof Pettersson

Against the background of a conventionalist theory, and staged as a defense of a naturalistic notion of names and naming, the critique of language developed in Plato's Cratylus does not only propose that human language, in contrast to the language of the gods, is bound to the realm of myth and lie. The dialogue also concludes by offering a set of reasons to think that knowledge of reality is not within the reach of our words. Interpretations of the dialogue's long etymological sections often neglect this critique and tend to end up with an overly optimistic assessment of the theory of language on offer. In the light of one of the dialogue's central etymological accounts - Socrates' etymology of the name Hermes - this paper discusses two recent and influential versions of such a view: David Sedley's theory of onomatopoetic encapsulation and Franco Trivigno's qualified referentialism. It argues that the complex relation between language and reality expressed in the Cratylus cannot be exhaustively captured by either of these theories because Plato considers all names to be semantically underdetermined until they are put to use. It suggests that Plato rather works with a functionalistic notion of names and naming, and that the dialogue's account of natural and correct naming is to be understood in these terms.

\section{Introduction}

At 407e5-408b3 in Plato's Cratylus, Socrates offers an etymological account of the name Hermes. Hermes, we learn, means contriver of speech, and as such the name pertains to the power of language. Although this passage has not been given proper attention in the literature $^{1}$, it is important for at least three reasons. First, it explicitly thematizes the Cratylus' main subject matter: language and the function of names. Second, it elucidates the joke that both initiates and concludes the dialogues' discussion of the correctness of names, i.e. why

\footnotetext{
${ }^{1}$ One important exception is Kirkland, S. D, 2007, 'Logos as the Message From the Gods: On the Etymology of Hermes in Plato's Cratylus' Bochumer Philosophisches Jahrbuch Fur Antike Und Mittelalter 12 (1): 1-14; Cf. also Ewegen, M, 2013, Plato's Cratylus: The Comedy of Language, Indiana University Press, esp.38; Sallis, J, 1996, Being and Logos: Reading the Platonic Dialogues, 3rd edn, Bloomington: Indiana University Press, 250-254; Riley, M.W, 2005, Plato's Cratylus: Argument, Form, and Structure, Amsterdam: Rodopi B.V; Barney, R, 2001, Names and Nature in Plato's Cratylus, New York and London: Routledge, 78-79. Ademollo, F. 2011, The Cratylus of Plato: A Commentary. Cambridge: Cambridge University Press, offers no discussion of this passage despite his comprehensive ambition, neither does Trivigno, F.V, 2012, 'Etymology and the Power of Names in Plato's Cratylus' Ancient Philosophy 32 (1). But see Sedley, D, 2003, Plato's Cratylus, New York: Cambridge University Press, 95-96.
} 
Cratylus claims that Hermogenes is wrongly named. And third, it is crucial for understanding what hides behind the main controversy of recent scholarship, that is, whether Socrates' etymologies in the Cratylus are meant to be serious or if their seriousness should rather be understood in the light of a larger parodic strategy. ${ }^{2}$

As a closer analysis of Socrates' etymology of the name Hermes will help to unravel, this controversy does to a large extent build on an unwarranted interpretative optimism in the sense that it is assumed that Plato makes Socrates explain how human language grants access to the truth about the existing things. On this view, much of the discussion has been about what semantic model best captures Plato's notion of names and naming. Yet, insofar as Plato does not, without careful qualification, accept the premise that reality can be elucidated by our words, the discussion may seem to be somewhat confused. What is needed, and what I will try to offer in this paper, is an assessment of Plato's explicit critique of language and an account of names and naming in the light of this critique.

In order to reach this end, I proceed as follows. In section one, I analyze the dialogue's concluding claim that knowledge of reality is beyond the reach of language. In section two, I discuss two recent and influential interpretations of the Cratylus that contend that Plato holds the opposite view: David Sedley's and Franco Trivigno's. Finally, in section tree, I offer a detailed analysis of Socrates' etymology of the name Hermes, and conclude by arguing that its emphasis on the (i) commercial, (ii) thievish and (iii) deceptive characteristics of language substantially qualifies the views of Sedley and Trivigno.

\footnotetext{
${ }^{2}$ Scholars that take the etymologies to be seriously meant philosophical accounts, include Findlay, J.N, 1973, Plato: The Written and Unwritten Doctrines, New York: Humanities Press; Sedley, D, 1998, 'The Etymologies in Plato's Cratylus' Journal of Hellenic Studies 118, 140-154; Sedley 2003; Sedley, D, 2007, 'Plato on Language' in H. H. Benson (ed.) A Companion to Plato, Malden, MA: Blackwell Publishing Ltd; Grote, G, 1867, Plato and the Other Companions of Socrates, Vol.2, London: J. Murray. Scholars that take them to be comic, playful or parodic, include Sallis 1975; Brock, R, 1990, 'Plato and Comedy' 39-49 in E.M. Craik (ed.) Owls to Athens: Essays on Classical Subjects Presented to Sir Kenneth Dover, Oxford: Clarendon Press; Arieti, J.A, 1991, Interpreting Plato: The Dialogues as Drama, Savage (Maryland): Rowman \& Littlefield; Gonzalez, F.J, 1998, Dialectic and Dialogue: Plato's Practice of Philosophical Inquiry, Evanston: Northwestern University Press; Nightingale, A, 2003, 'Subtext and Subterfuge in Plato's Cratylus' 223-240, in A.N. Michelini (ed.) Plato as Author: The Rhetoric of Philosophy, Leiden: Brill. On the other hand, Trivigno 2012; Ewegen 2014; Barney 1998 and Barney, R, 1998, 'Socrates Agonistes: the Case of the Cratylus Etymologies' Oxford Studies in Ancient Philosophy 16: 63-98, move beyond this dichotomy and suggest that the serious purpose of the etymologies must be seen in the light of their parodic intention.
} 


\section{A Reality Beyond Names}

Plato's Cratylus ends inconclusively. Both Cratylus' naturalist suggestion, that "he who knows the names knows the things" (435d4-6), and Hermogenes' conventionalist model, that the informative power of language rests on how its basic constituents, the names (cf. 385c7-8), are established by convention, has turned out to be inadequate in their stated forms. ${ }^{3}$ In Socrates' concluding discussion with Cratylus, he also suggests that the very subject matter may have distorted their inquiry: "He who in his inquiry after things ( $\tau \grave{\alpha}$

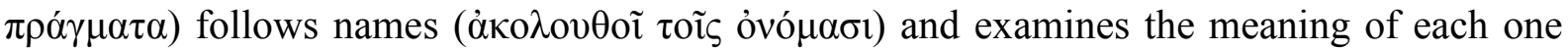

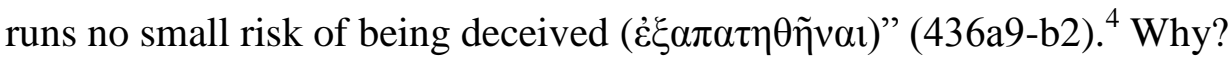

On the assumption that the primary function of language is to encapsulate or represent reality, Socrates submits that an inquiry into its parts and constituents may lead astray. Insofar

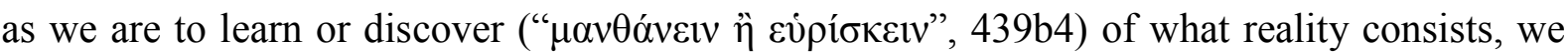
need to pursue some other path than the study of language and names. But, as Socrates also points out, although

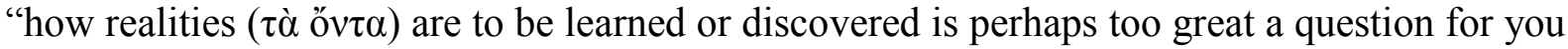
and me to determine [...] it is worthwhile to have reached even this conclusion, that they are to be learned and sought for, not from names but rather through themselves than through names" (439b4-8).

Even if this conclusion may seem to undermine the interpretative optimism with which the Cratylus is often read, Socrates is not reluctant to explain. Language is not to be trusted, for at least three reasons:

First, because our words or names ${ }^{5}$ are inherited, Socrates concedes that it is sensible to talk about their origin and nature in terms of how they were once established by a number

\footnotetext{
${ }^{3}$ So Silverman, A, 2001, 'The End of the Cratylus' Ancient Philosophy 21 (1): 25-43, esp. 29-32; cf. Mackenzie, M.M, 1986, 'Putting the Cratylus in its Place' Classical Quarterly 36 (1): 124-150.

${ }^{4}$ All translations are based on Reeve, C.D.C, 1997, in Cooper (ed.), Plato: Complete Works. Indianapolis: Hackett, and Fowler, H.N, 1921, in Plato in Twelve Volumes, Vol.12, Cambridge, MA: Harvard University Press, London: William Heinemann Ltd.

5 'Words' or 'names' translate ỏvó $\mu \alpha \tau \alpha$. This term does however cover more than our 'names' but less than our 'words'. It includes proper names, common nouns, infinitives and adjectives. Henceforth I will use 'names', since this has become custom in the literature. Cf. Trivigno 2012, 35n3; Sedley 2003, 4; Ketchum, R.J, 1979, 'Names, Forms and Conventionalism: Cratylus, 383-395' Phronesis 24 (2), 133; Kretzmann, N, 1971, 'Plato on the Correctness of Names' American Philosophical Quarterly 8 (2): 126-138, 126n1; Anagnostopoulos, G, 1972, 'Plato's Cratylus: The Two Theories of the Correctness of Names' Review of Metaphysics 25 (4), 693-695. See also LSJ s.v.
} 
of original name-makers. ${ }^{6}$ Even if it is not obvious whether we should understand these namemakers and their originality in a literal or a metaphorical sense, their argumentative function is sufficiently clear. When the names were once established ( $\dot{\varepsilon} \tau \dot{i} \theta \varepsilon v \tau o$ ), they were established in accordance with the name-makers' conception of reality (436b5-7). But, as Socrates now points out, because we cannot know whether they had things right, we must be cautious. Even if the names that they established perfectly correspond to reality as they understood it, we will repeat their (possible) mistakes if we follow them (436b9-11). Cratylus is not convinced. Surely, he says, the original name-makers knew what they were talking about. A name, he insists, is only a name if it is correct, and because the names are consistent or in harmony ( $\sigma 0 ́ \mu \varphi \omega v o \varsigma, 436 \mathrm{c} 4)$ it is clear that they pick out what is real. Insofar as the names agree with

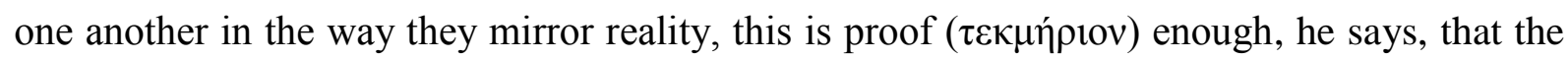
name-makers "did not miss the truth" (436c3). Thus articulating what could be said to be a strong version of a conventionalist's account modeled in naturalist's terms, Cratylus draws on the seemingly consistent results of Socrates' preceding etymological investigation. As Cratylus insists, Socrates' analysis of the names has shown that they all tend in the same direction. Most, or at least a majority, of the etymologies revealed a general Heracleitian propensity. They showed that things are in motion. Accordingly, the names seem to support each other and as such they make up a coherent and sufficiently unified whole. The names, Cratylus insists, were all "formed with the same method and with the same end in view" (436c5-6).

Second, Socrates replies by pointing out that consistency is no guarantee for truth: "If the givers of names erred in the beginning", he says, "and henceforth forced all other names into agreement with his initial error, there is nothing strange about that" (436c8-d1). Further, Socrates doubts that there is such a consistency at all. In order to substantiate this claim, he

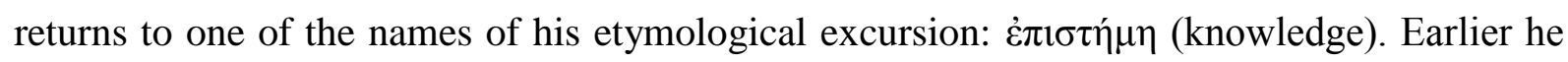

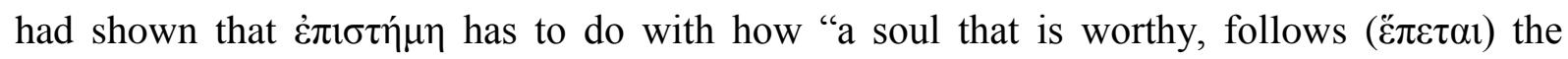
movement of things [and that one thus] ought to insert an $\varepsilon$ and make the name $\dot{\varepsilon} \pi \varepsilon i ̈ \sigma \tau \eta \dot{\mu \eta}$ " (412a1-4). Now, however, Socrates argues that it would be equally sound to think that

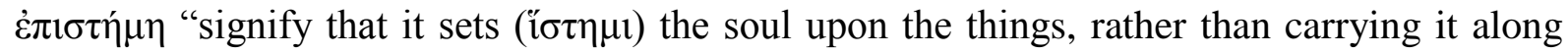

\footnotetext{
${ }^{6}$ The idea of the original name-makers is introduced as a part of Socrates' initial argument to refute Hermogenes' conventionalist position. Socrates refers to them in at least four different ways: as law-

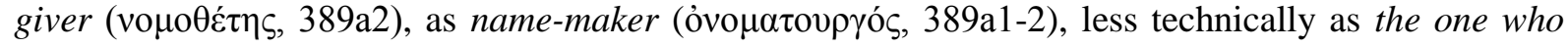

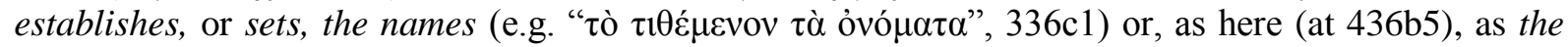

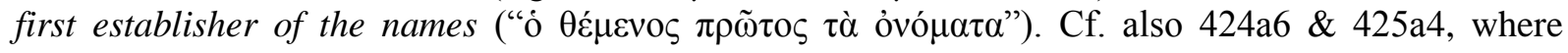

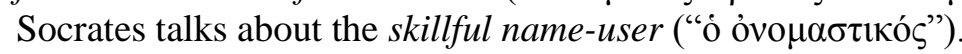


with them, so that it is more correct to say the beginning [i.e. $\dot{\varepsilon} \pi 1$ ] as we do now, rather than inserting an $\varepsilon$ to make $\dot{\varepsilon} \varepsilon \varepsilon \ddot{i} \sigma \tau \dot{\mu} \mu$ " (437a2-7). ${ }^{7}$ As it turns out, these equally sound-sounding etymologies contradict one another and this indicates that this name really is quite ambiguous

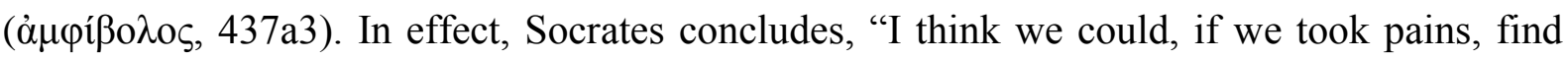
many other words which would lead us to reverse our judgment and believe that things were not in progress or in motion, but at rest" (437c5-8). Not even the fact that most names seem to indicate that reality is in motion will do, we learn, because the truth of reality cannot be a matter of counting votes (437d3-4). Cratylus consents.

Third, as Socrates returns to Cratylus' claim that the original name-makers knew what they were talking about, he raises another doubt. How, he asks, did the original name-makers acquire their knowledge "if things cannot be learned except through their names" (438b7-8)? Conscious of the marvelous force of Socrates' question, Cratylus answers that the "power which gave the first names to things is more than human, and therefore the names are correct" (438c2-4). Socrates worries that this superhuman origin cannot be true. Referring back to Cratylus' consent to the conclusion that many of the names have ambiguous and contradictory meanings, Socrates asks about Cratylus' opinion: "Then, in your opinion, he who gave the names, though he was a spirit ( $\delta \alpha i ́ \mu \omega v)$ or a god $(\theta \varepsilon$ ó $\varsigma)$, would have given names which made him contradict himself?" (438c5-6). Cratylus cannot of course consent to this. He cannot allow that what is divine contains a contradiction. And even if Cratylus goes on to suggest that it would thus perhaps only be one half of the names that are correct, Socrates repeats his point about the votes and Cratylus realizes that the matter is not to be determined by mere numbers. Accordingly, Cratylus is also forced to go along as Socrates puts the final nail in the coffin. Insofar as the same name says both this and that, we need some other point of reference and this cannot be a name:

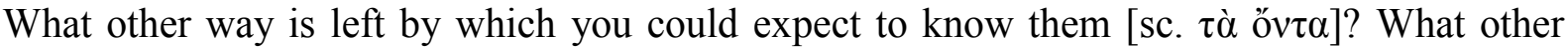
than the natural and the straightest way, through each other, if they are akin, and through themselves? For that [sc. the names] which is other and different from them would signify ( $\sigma \eta \mu \alpha i v o r)$ not them, but something other and different (438e5-9).

Language is no short-cut to reality. While the names signify themselves and their own different meanings, it is only the things that signify the things. As such, this passage is also in line with the general orientation of Socrates' arguments in this section. ${ }^{8}$ Language is not to be

\footnotetext{
${ }^{7}$ Trivigno 2001, 62, makes a similar point.

${ }^{8}$ For a different point of view, see Ademollo 2011, 446ff. Cf. also Thomas, J.C, 2008, 'Inquiry Without Names in Plato's Cratylus' Journal of the History of Philosophy 46 (3).
} 
trusted, first, because it is a mistake to think that the names contain infallible information about reality, second, because the names do not have divine origin, and third, then, because the names signify something different than the things and can therefore not be trusted to refer to some determined part of reality except than to themselves.

\section{The Mirror of Reality}

Socrates' argument at the end of the Cratylus does, of course, raise serious semantic and epistemic problems. Read in isolation, it does not only leave the basic function of names and naming unexplained. As such, it also sanctions the view that all linguistic expressions are inadequate and deceptive. Perhaps it is for these reasons that many readers of the Cratylus often favor other parts of the dialogue. In the longer etymological sections, for example, or in the introductory treatment of names and naming, Plato may be said to presents a much more optimistic view. The question is how these passages are to be reconciled.

In order to assess what is at stake here, and before I turn to what Socrates has to say about names and language in connection to his etymology of the name Hermes, I will begin by analyzing two recent and influential accounts that, despite their differences, share this optimism, namely David Sedley's and Franco Trivigno's.

David Sedley, first, concludes one of his seminal works on the Cratylus by the claim that "Plato's conviction [is] that our languages [...] have an objectively determined structure which from the start is isomorphic with the structure of reality" $(2007,223)$. According to Sedley, it is also this isomorphic structure that justifies the science of the etymologists; in the defense of which he claims that the Cratylus was written in the first place. Endowed with the ability to decode a reality encapsulated in the basic constituents of our languages, Sedley contends that Plato thinks that the etymologists can reveal the truth hidden in the names.

Sedley's account of the Cratylus has recently been called into question. While acknowledging the importance of Sedley's research, Franco Trivigno (2012) has argued that Sedley's unwillingness to appreciate the dialogues' playful character and the comedic purpose of the etymologies makes his position unrealistic. If we deny that "comedy can have [...] serious meaning" $(2012,36)$ and that the absurdity of Socrates' etymological excursion is meant to show how a referential-based use of names outwits an inquiry into their descriptive contents, Trivigno worries that the discussion in the Cratylus is reduced to a question of who finds what ridiculous $(2012,36)$. However, as Trivigno also acknowledges $(2012,36)$, Sedley 
is clearly aware of this problem (cf. 2003, 37-38) and despite Trivigno's detailed and sharp critique, a closer look will reveal that they have much in common.

Most notably, as we shall see, they both seem to believe that Plato's purpose with the Cratylus is to offers a coherent and exhaustive theory of how language can capture or mirror reality. While Sedley argues that this is a matter of encapsulating the truth of the existing things in the sounds and letters of the names, Trivigno suggests that it is a matter of a structure of reference and that this pertains to the ability to denominate real and stable things. As we have seen, and as shall become more evident as we go along, Plato's text indicates that there is no such theory on offer and that the dialogue's purpose is to be sought elsewhere (439b4-8). But why, then, do both Sedley and Trivigno claim the opposite? Let us take a closer look.

Sedley's claim that Plato thinks that the nature of human language can be exhausted in terms of its ability to capture or mirror reality can be said to be substantiated in three ways. He argues (i) that the names "encapsulates the nature" $(2007,216)$ of the things, (ii) that the names, on Plato's account, must to some extent be considered to have "superhuman" origin (cf. 1998, 144), and (iii) that in consequence of the impact of "generations of use" $(2003,48)$ the names have been distorted, and the task of the etymologist is to clarify these distortions and adequately decipher the original names and their meaning.

First, with reference to Socrates' introductory account of names and naming (385e390e), Sedley argues that "a name is an expertly crafted tool for objective ontological analysis" $(1998,141)$. A name is not an arbitrary collection of sounds or letters, but an independent and self-contained encapsulation of the nature of the thing it names. According to Sedley, a name must accordingly satisfy two criteria: "[A]ny unified string of sounds that (a) has been assigned to a thing and (b) descriptively picks that thing out qualifies as a name" (2007, 218). Sedley explains what this requires in terms of the original name-makers. "Their construction", he argues, "involved subtle compression of a whole message into just as few syllables" (2007, 216). Accordingly, a name can be understood as a cipher or a code that, correctly deciphered, can be shown to capture the nature of the thing it was originally designed to denominate.

One important thing to keep in mind here is that although the names thus construed are region, language or dialect specific, there is a mediating factor that conditions the construction. As Sedley correctly points out, there can be "two or more names for the same thing - as indeed, at least across languages, there undeniably is" $(2007,218)$. According to Sedley, this is to be explained in terms of what he calls the Form of Name, or, short, the 
name-Form. In order to encompass Socrates' claim that the correctness of a name should ultimately be judged in accordance with its use and function, and thus independent of specific sounds (cf. 390c-d), Sedley argues that we must assume that there is an immaterial and real name that informs the embodied names, i.e. the ones with sounds or letters.

Sedley argues that these immaterial name-Forms do not only have the same origin as the other Forms (cf. 439b10-d1 and onwards). They are also somehow metaphysically bound to the things they name (Sedley 2003, 82n13). Sedley further analyses the name-Forms in a generic and a specific category. While the generic name-Form is the very form-Form of the Name, the specific name-Form is, "say, the Form of the name of dog" $(2003,82)$. The function of this specific name-Form "is giving instruction by vocally separating what a dog is" $(2003,82)$. And this is necessary, he argues, because if one would try to embody the formForm of a dog directly, one would not end up with a name, but with a dog $(2003,82)$. A (correct) name is thus not an embodied thing, but the embodiment of a (specific) name-Form (2003, 66; 2007, 219). This embodiment can be more or less comprehensive, but in order to be correct it must always, at a minimum, express some aspect of the name-Form, and thus indirectly of the reality which this name-Form is a name of $(2003,83)$. In this way it is also clear that the same name-Form can be expressed by different sounds and, in effect, in different languages. Sedley puts it in this way: "Just as the precise wood or metal used by an ordinary manufacturer may vary without determent to his product, so the sound system in which the name-maker creates names will vary according to his nationality" $(2003,66)$.

Second, besides arguing that there are reasons to think that the names, on Plato's account, are independent - in the sense that they encapsulate their own meaning regardless of their use and function - Sedley also offers another reason to consider language a mirror of reality. If Plato did not think that an inquiry into the origin of language was worthwhile, he would not have dedicated an entire dialogue to the matter. In order to explain the Cratylus' extraordinary dedication to etymology and to the origins of the names, the argument goes, it is reasonable to suspect that Plato considered this task to have some lucrative payoff. Even if Sedley acknowledges that Plato did not consider the original name-makers to be gods, he insists that both Socrates and Cratylus "suggest that [the name-makers] may have been somehow superhuman" (1998, 144). Their "coinage show real insight" $(2007,217)$ and insofar as the names are only correct if they to some extent manage to be "encapsulations of thing's natures" $(2007,218)$, the original name-makers did show such "genuine and even seminal insights" $(2003,98)$ that it is worth repeating. In order to lend added weight to these claims, Sedley refers to what he considers to be Plato's general notion of time and 
development. Arguably, Plato was not particularly original in this field. Instead he shared the "[virtually universal] assumption that language was a deliberate contrivance by primeval individuals (human or superhuman)" (2003, 71). In the Cratylus, Sedley insists, Socrates twice "voices [the] suspicion" that the name-makers were "superior to us and living closer to the gods" (2003, 30). From Plato's point of view, Sedley argues, "the ancients either were divine or hade divine sources of information" $(2003,32)$. Just as Aristotle, and long before Epicurus' alternative explanation of language development, Plato entertained the thought of "our early ancestors' proximity to their divine origin" (2003, 32). And even if "Plato [does not reveal] how these distant ancestors might have obtained their divine insights" $(2003,33)$, Sedley offers no reasons to doubt that Plato held this view.

Third, all of this speaks in favor for the importance of the etymologist's task. The original names were designed to capture, enclose and encapsulate the nature of reality, as they understood it, in short-code. And even if the name-makers may not always have been comprehensive or even right, their superior sources of information make it reasonable to suspect that it is worthwhile to attempt to recover what they buried in the names. Besides the difficulties that this task itself mounts in terms of decoding, Sedley also identifies a second obstacle. The names are subjects to deforming "morphological changes" (1998, 148). With the impact of time, parts of the sounds and letters that made up the original names have been taken away and replaced. Sedley calls this an "additional cloak of distortion" and explains that even if this makes the task of the etymologists harder, they can still "learn to strip away the more recent accretions and ignore the sound-shifts, instead identifying and concentrating on the original hard core of each sound-complex" $(2003,48) .{ }^{9}$ Accordingly, two things are clear: "Our job as etymologists is not to repeat the work of the name-makers, but to reverse it, decomposing what they composed and thereby decoding what thy encoded" $(2003,42)$. And even if "the early names are still with us [i.e. with Plato], [they] usually [are] in a corrupted form, so that recovery of their original form and meaning requires expertise" $(2003,34)$.

In outlining the expertise involved here, Sedley is careful to point out that the etymologist must not always be successful (2003, 41). Expertise is not infallibility (cf. 2003, 44). Socrates' own practice of etymology, Sedley argues, is telling. "Socrates is a tyro at etymological science, relying, as he keeps reminding us, on inspiration rather than training"

\footnotetext{
9 "A further limitation", Sedley 2003, 48, goes on, "is that for some words etymological analysis is bound to fail because they are foreign imports, composed on non-Greek principles (409d-410a). Again, and for the same reasons, this limitation need not be fatal to the entire enterprise, which, like all skills, should never have aspired to 100 percent success."
} 
(2003, 49). This, Sedley insists, is an important qualification. Rather than being like the shipbuilders or the cobblers, the etymologists are more similar to the diviners. Etymology is not a matter of correct measurement or precise rules, but involves a fair amount of intuition and the ability to apply familiar principles to unfamiliar situations. Socrates' claim that his whole etymological enterprise in the Cratylus was inspired by Euthyphro, the famous diviner, is telling (cf. Sedley 1998, 145). Considered from this perspective, it also makes sense that the results that the etymologists produce are not always perfect or exhaustive. In addition, it is also important to see the limitations of the etymologists' task. Even if they manage to recover the original name-makers' secrets, it is not certain that the name-makers always had it right. But this, of course, is not the etymologists' fault. In order to make this point, Sedley distinguishes between what he calls exegetical and philosophical correctness. While all etymologies that are accurately made are "exegetically correct, in that they do recover the original beliefs of the name-makers, $[\ldots]$ it remains a moot point whether they are also philosophically correct, that is whether [...] the beliefs they recover for us are true beliefs" $(2003,28)$. For Sedley, this point is however less moot than he makes it seem. As it turns out, he considers several of Socrates' etymologies in the Cratylus to be philosophically correct: "[In the Cratylus] etymology works as an exegetical device [and it offers] us a whole range of decodings which any Platonically attuned reader will recognise as philosophically correct" $(2003,98)$.

Franco Trivigno (2012) articulates a set of important considerations meant to destabilize Sedley's position. In general, Trivigno thinks that Sedley fails to pay sufficient heed to the playful character of the etymologies, and that this makes his point of view untenable. On Trivigno's view and in clear contrast to Sedley's, Socrates does not only manage to show that "one can use etymology to make names mean anything whatever one wants" (54). Trivigno also shows how etymology, at best, can "reveal the belief of the etymologist projected onto the names and thus back onto the original name-makers" (59).

Besides referring to Socrates' repeated point that he is not committed to the etymologies he articulates (e.g. 391a4-6, 396d4-8, 396d8-397a1; cf. 413d7-8, 428a1-3, $428 d 2)$, Trivigno defends this view with reference to $414 d 7-9$ where Socrates puts it in the following way: "If we are allowed to add or subtract whatever we want to names, then it will be far too easy and we would be able to fit every name to every thing" (52). Reading this passage as an explicit renunciation of the etymological method Socrates actually practices in the Cratylus, Trivigno argues that large parts of the Cratylus must be understood as parody. Instead of revealing what the original name-makers understood of the world, as Sedley has it, 
Trivigno argues that Socrates' ultimate aim with the etymologies is to exhibit the absurdity of thinking that sounds and letters, however skillfully combined, can contain descriptive, stable and recoverable information about reality. On Trivigno's view, Socrates rather shows that the names are quite ambivalent and that their sounds and letters cannot be trusted in this way.

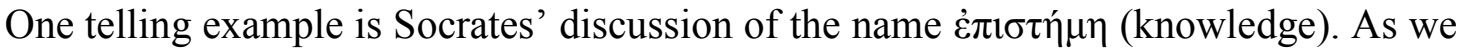
have seen, and as Trivigno emphasizes, Socrates' discussion in connection to his second etymology of this name (at 437a2-7) shows "that all names, or at least a great many of them, are ambiguous" (62). According to Trivigno, this means two things. It means that Socrates has no trust in what Sedley would describe as the encapsulating capacity of the names and that any information that the etymologists claim to recover from the names has its source in the etymologists themselves.

To lend further weight to this interpretation, Trivigno introduces what he calls Socrates' strategy of parodic amplification (44). In order to encompass the fact that Socrates does articulate a set of etymologies that appear to be both exegetically and philosophically correct, as Sedley has it, Trivigno suggests that Socrates' argument proceeds with an etymologically attuned addressee in mind. ${ }^{10}$ Accordingly, Socrates begins with cases that such an addressee would find sound. He makes the initial etymologies harmonious and sufficiently consistent. In this way he is not only able to establish a basic trust, he can also proceed to more and more dubious cases by applying the principles established in the first and eventually point their absurdities out. Accordingly to Trivigno, this is not only an implicit or underlying method (46). Socrates' repeated claim that he "cannot believe" $(428 \mathrm{~d} 2)$ the results of his various etymological exercises makes it quite explicit (e.g. 391a4-6, 396d4-8, 396d8397a1, 413d7-8, 428a1-3). "In short [Socrates' strategy of parodic amplification] functions as a reductio ad absurdum" (46). ${ }^{11}$

In the light of Trivigno's general interpretative strategy, his account of the Cratylus is quite different from Sedley's. If we take a closer look at the details, however, there are several factors that make their accounts importantly similar. Not only do they both contend that Plato considers language a mirror of reality. Just as Sedley, Trivigno also confirms this contention in terms of the (i) independent, (ii) superhuman and (iii) truth revealing capacity of the names:

\footnotetext{
${ }^{10}$ In the days of the sophists, when etymology was "a flourishing activity" as Sedley 2007, 217 puts it, this strategy would perhaps seem more urgent than today.

${ }^{11}$ Trivigno 2012, 44-45, draws the parallel to Aristophanes and the Clouds. Here, Trivigno argues, just as in the Cratylus, the absurdities are not only slowly augmented. Ultimately they are also explicitly pointed out.
} 
First, in line with the general direction of Sedley's argument, Trivigno correctly considers Socrates' initial account of the names and their function (386e-391b) to be "quite serious" (43). In contrast to Sedley, he does however not think that this means that the "correctness of a name consists in its constituents, i.e. syllables and letters, being naturally suited to refer to the object in question" (43). According to Trivigno, "the correctness of a name [does instead] consist in its referring to a stable nature" (43).

In order to vindicate this claim Trivigno refers to 393d1-4 (43). Here, Socrates does not only claim that "it makes no difference whether the same letters or different ones signify ( $\sigma \eta \mu \alpha i v \varepsilon l)$ the same thing". Socrates also suggests that it does not "matter if some letter is

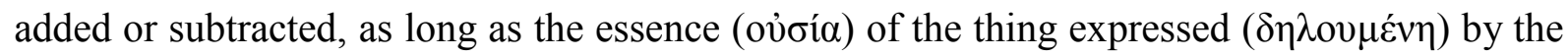
name is in control". 12 Trivigno takes this passage to be an explicit rejection of Sedley's claim that the names' letters and sounds are encoded encapsulations of descriptive contents. In addition, yet in sharp contrast to what Socrates argues at 438e5-9, Trivigno also takes this passage to be an unambiguous endorsement of the idea that a name can refer to a stable nature and signify something real (44). Drawing on an important but highly contested passage in Socrates' account of the function of the names, Trivigno reaches this conclusion by the method of elimination:

At 387d4-5 Socrates says that "we must name things in a natural way for them to be named and with what is natural for naming them". ${ }^{13}$ According to Trivigno this can be taken to mean at least two things. It can mean (1) that the names are natural and correct by referring to stable natures, (2) that the names are natural and correct if their sounds and letters are "naturally suited to refer to the object in question" or both (44). Since Trivigno takes Socrates to be rejecting (2), he concludes that (1) must be the right interpretation. And indeed, as Trivigno reaches this conclusion, he also argues that it is in terms of establishing trustworthy references that we should understand Socrates' description of the process of name-formation.

Besides the skill of the name-makers and the regulatory supervision of the dialecticians (to which we shall have reasons to return), Trivigno points out that this process "involves appealing to each thing's natural name for guidance" (43). ${ }^{14}$ Although he does not elaborate the point, this concession is important for two reasons. First, it helps to explain how

\footnotetext{
${ }^{12}$ Trivigno's translation and parentheses.

${ }^{13}$ Cf. Sedley 2003, 82-83 \& 60-61; Gonzales 1998, 68-69; Sallis 1974, 208.

${ }^{14}$ Emphasis added.
} 
Trivigno understands reference, and second, it shows that Trivigno basically agrees with Sedley.

As Trivigno explains in a clarifying footnote (43n19), a natural name is the same as what Sedley calls a name-Form. ${ }^{15}$ This does not only mean that Trivigno thinks that the natural correctness of the names is established in a process that is guided by a useindependent entity with a solid and metaphysical bond to ultimate reality. It also means that Trivigno think that this name-Form functions as a mediating factor for reference. If the nameForm is to play any part in the process of name-formation, as Trivigno seems to think, it must be as a link between the individual name and reality. In this way, it is the name-Form that makes reference possible. Accordingly, even if Trivigno does not think that the choice of letters and sounds are relevant, as Sedley does, they both share the same basic explanatory model: The individual name is formed in a process that is guided by a silent, independent, self-contained and invisible name-Form, and this process secures that the individual name, when used in a correct way, will, in one way or another, put its user in contact with reality. As we shall see, there are reasons to doubt that the text actually support this model and the notion of a name-Form it implies. But insofar as Trivigno thinks that such a Form is involved in the process of name-formation, he is committed to its mediating function. For Trivigno, just as for Sedley, the individual names' ability to mirror reality is conditioned by the independence of the name-Forms.

Second, another important question that seems to set Sedley and Trivigno apart concerns the status of the original name-makers. While Sedley thinks that they must be considered to have some kind of superhuman source of information, Trivigno argues that this is an absurd conclusion to draw. Trivigno's critique of Sedley on this point is quite persuasive, but as it turns out, his own account does not actually differ that much from Sedley's. At the end of the day, Trivigno also believes that the names can have superhuman status, even if he initially is quite dismissive of the idea $(2012,42)$ :

First, Socrates himself goes to great lengths to point out that the beliefs of the original namemakers are not necessarily to be trusted (e.g., 429a-b). How is one to discern, in advance of possessing knowledge of $X$, that the name-makers correctly encoded ' $X$ ', and thus that decoding ' $\mathrm{X}$ ' will lead one to a philosophically correct view? In order to find a reason to pursue the etymology of ' $X$ ', one would need independent knowledge of $X$, which would thereby render the etymology superfluous. Thus, we seem to have a positive reason not to decode names, but rather to seek independent knowledge of $\mathrm{X}$. Indeed, this is just what Socrates recommends (439a).

\footnotetext{
${ }^{15}$ Or more specific: “a species-Form of a name” Trivigno 2012, 43n19. Cf. Sedley 2003, 82.
} 
Here Trivigno says at least two things. On the one hand, he says that Socrates does not think that the original name-makers had access to any privileged information, and, on the other, that even if they had, etymology is not the best way to access that information. "Indeed", Trivigno goes on, "given the endemic ambiguity of names (437a-d) and the unreliability of those who set them down (436b-e), names will never be more than imperfect guides to the metaphysics of the universe" (70). As it turns out, Trivigno's claim that the names are imperfect is however quite modest. Because when used in the right way, as it puts it, they can indeed help us to uncover reality. Again, Trivigno spells this out in terms of reference. Even if he does not think that Plato believes in divine name-makers, Trivigno certainly suggests that the names can have superhuman status. Insofar as a "name has an actual referent" it is "naturally correct" (70). This means (a) that a naturally correct name "refer[s] to a stable nature" (42) and (b) that "names [...] are subordinate to things" (70). When used in the right way, the names make it possible to talk about the real and "stable objects of knowledge" (43) because the names' subordination to this reality secures their accuracy. In contrast to names that do not have a stable and actual referent, such as “discredited scientific concepts like 'humor', nonsense words like 'loopdid' or terms picking out arbitrary aggregates like 'barbarian'" (70), names with real reference are trustworthy. In being linked to the real things in a real Platonic universe, they are not only immune to ambiguous signification and misguided reference. Their truth is also secured by proper practice.

This, then, leads us to the third point and is connected with Trivigno's critique of Sedley's account of the practice of etymology. Because just as Sedley, Trivigno also seems to argue that Plato thinks that the ultimate purpose of any discursive activity is to describe and reveal the nature of reality. Even if Sedley and Trivigno identify different heroes and different means, they describe the goal and the tools in the same terms. While Sedley argues that Plato thinks that it is the task of the etymologists to decode the names and expose the structure of reality, Trivigno suggests that it is only the dialecticians that can accomplish this task.

Although Trivigno writes that the dialecticians focus their "inquiry on the thing itself and not [on] the imitation, i.e. the name" (70), this does not mean that he thinks that the natural correctness of the names can be discerned in any other practice than the dialectical. It is in dialectical inquiry that a name shows that it has "an actual referent" (70) and it is as the dialecticians' tools that the names are able to refer to a superhuman reality, inaccessible to the rest of us. Accordingly, two things are clear. Trivigno does not only consider the dialecticians 
to have privileged access to the things themselves, i.e. the referents. He also considers dialectic to be an instrumental pursuit.

Although Trivigno mentions the importance of the interpersonal character of dialectic (69-70), his account assumes that the dialecticians know what is real and that they can communicate this knowledge. The dialecticians, as Trivigno puts is, "will be able to teach and divide being" (70). They will be able to teach and "divide things according to how they are" (43) and the names, he insists, "will not accomplish this task on their own" (70).

Even if Trivigno correctly points out that Socrates' aim is not to lay the grounds for the absurd idea of an ideal language ${ }^{16}$ - where each word have its precise and stable definition - he nevertheless thinks that "dialectical inquiry puts names to philosophical use in a dialogue that attempts to understand the referents themselves" and that the "results of dialectical analyses" (70), which he supposedly considers a discursive pursuit, "is epistemic contact with [the thing itself]" (72). If Trivigno is right, this means that the dialectical pursuit Socrates is suggesting has a transcendental orientation and that it is directed at the things; not however at the things we normally call 'things', such as trees and clouds, but at the "real" things, accessible only by the superior minds of the dialecticians. In contrast to a practice that would have an immanent orientation, by being aimed at elucidation of what we believe and say about our experiences of the world and the (ordinary) things in it, Trivigno's account of dialectic, and his insistence that the dialecticians' use of the names are subordinate to the things, implies that it is only the epistemic and transcendental results of the dialectical process that makes it valuable. ${ }^{17}$

In sum, although Trivigno's account of the purpose of the etymologies in the Cratylus is importantly different from Sedley's, a closer look at the details shows that they have much in common. Just as Sedley, Trivigno argues that Plato's account of the natural correctness of the names involves (i) the notion of a natural name or a name-Form, (ii) the correlation to a transcendental source of knowledge and, in effect, (iii) the capacity to capture ultimate reality.

\footnotetext{
${ }^{16}$ Pace e.g. Weingartner, R, 1970, 'Making Sense of the Cratylus' Phronesis 15, 14-16; Kretzmann 1971, 137; Anagnostopolous 1972, 729; Baxter, T, 1992, The Cratylus: Plato's Critique of Naming, Leiden, New York, Köln: Brill, chs. 2 \& 3. Gonzalez 1998, 78-81, agrees with Trivigno 2001.

${ }^{17}$ Cf. Apol. 38a2-3.
} 


\section{The Legacy of Hermes}

Besides Socrates' explicit suggestions that it is a mistake to think that the names contain infallible information about the things, that the names do not have divine origin, and that language cannot signify reality - as we saw in section one - the Cratylus also offers a set of further reasons to think that Plato has a much less optimistic notion of language than what Sedley and Trivigno wants to admit. One passage that turns out to be especially helpful in establishing the scope of Plato's critique of language is introduced as a part of Socrates' etymological investigation of the names of the gods: the etymology of the name Hermes (E $\rho \mu \tilde{\eta} \varsigma)$. Having just explained to Hermogenes that he is afraid to pursue these matters (407d6-9), Socrates nevertheless agrees to risk one more on the grounds that it has to do with Hermogenes name. Socrates spells it out in the following way:

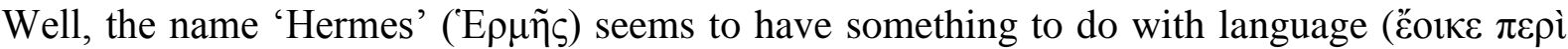

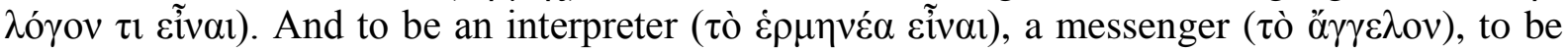

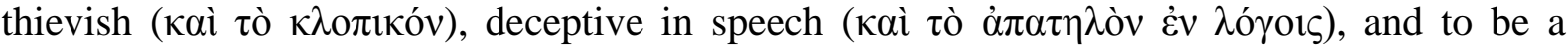

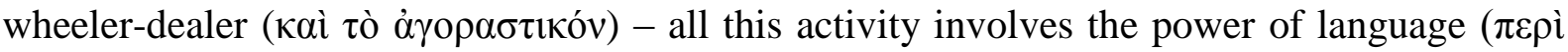

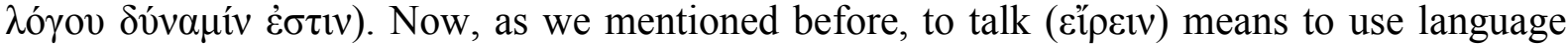

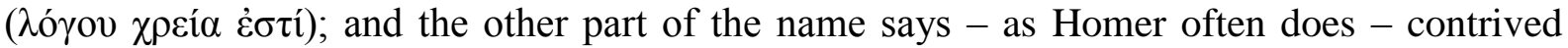

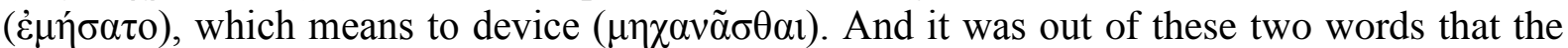
lawgiver [or name-maker] established the name of the god who devised speech and language,

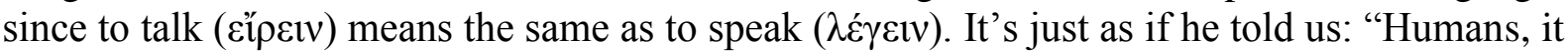

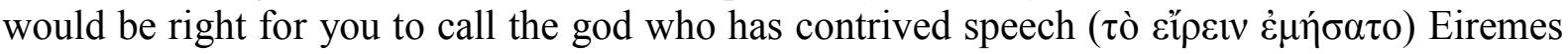

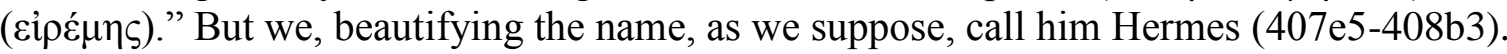

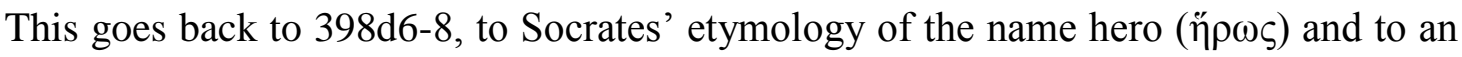
account that equated the wisdom of the rhetoricians with that of the dialecticians. ${ }^{18}$ There we

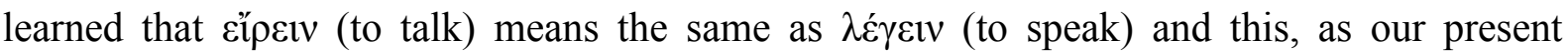

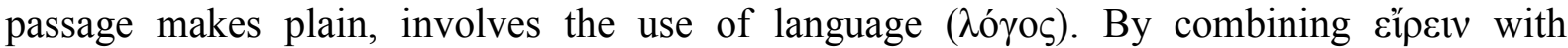
$\dot{\varepsilon} \mu \eta \dot{\sigma} \sigma \alpha \tau$, the aorist of $\mu \eta \dot{\delta o} \mu \alpha \iota$ (plan and do cunningly), which according to Socrates means

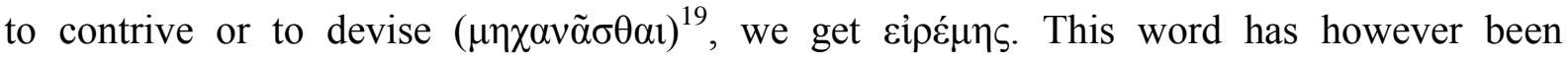

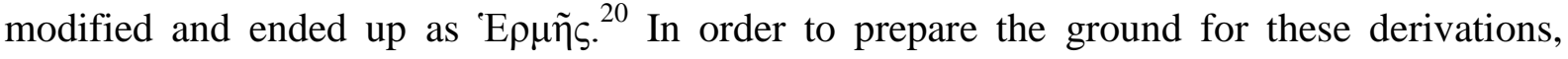

\footnotetext{
${ }^{18}$ At 398d6-8 Socrates suggests that the word $\eta \rho \omega \varsigma$ means that the heroes "were wise and clever

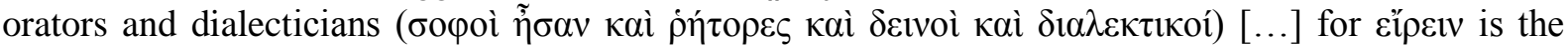
same as $\lambda \dot{\varepsilon} \gamma \varepsilon ı v^{\prime \prime}$.

${ }^{19}$ At 415a4-9 $\mu \eta \chi \alpha v \eta$ gets its own explanatory etymology, the etymology that Socrates calls the head

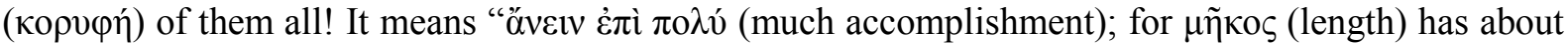

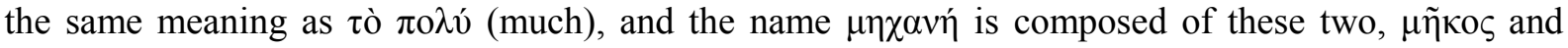
öveıv".

${ }^{20}$ For a slightly different account, see Ewegen 2014, 45-49.
} 
Socrates begins by articulating a set of general observations. Besides the less controversial point that language has with interpretation and messaging to $\mathrm{do}^{21}$, he also isolates and identifies three more puzzling characteristics pertaining to Hermes and the power of language.

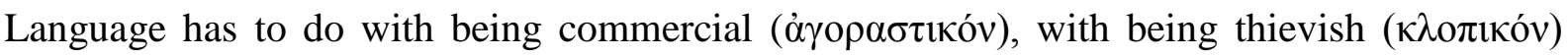

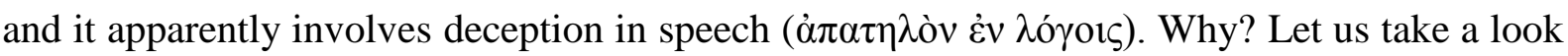
at these characteristics, one at a time.

(i) Correctness and Commerce

At 384b6-384a7, where Socrates and Hermogenes have just initiated their conversation about the names and their correctness, Hermogenes asks Socrates to explain a joke. Hermogenes does not understand why Cratylus claims that Hermogenes name is wrong and why this is funny. Cratylus, as Hermogenes importantly points out, is not willing to explain. ${ }^{22}$ In line with his general evasiveness, evidenced by his unwillingness to say more than three words (383a3) in the first 65 pages of the 86 page dialogue, Cratylus refuses to say what he means. ${ }^{23}$ Instead, it is Socrates that does the talking. Most likely, Socrates says to Hermogenes, Cratylus is trying to have some fun one your account, because "you, in wanting

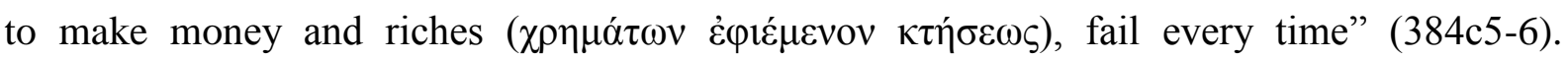
Although Socrates does not offer more explanation than this until 408a1, the point is supposedly this: Hermogenes' name is wrong because Hermogenes - which means something like the son or offspring of Hermes - has not inherited his ancestor's features. If Hermogenes'

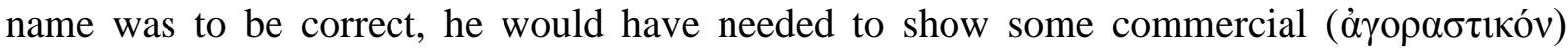
orientation. He would have needed to display that he had some characteristic that would make him like the bargainer, the monger or the wheeler-dealer. ${ }^{24}$ As Socrates soon shall come to

\footnotetext{
${ }^{21}$ For discussion, see Kirkland 2008, esp.9-10; Barney 2001, 78-79; Ewegen 2014, 40-49.

${ }^{22}$ At 429b12-c5, Socrates returns to the peculiarities of Hermogenes name, and again asks Cratylus what he means when he says that Hermogenes does not have the correct name. At this point, Cratylus is however more willing to speak than before. As we shall see, this is an important dramatic change

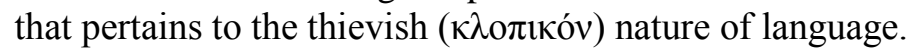

23 "Note that Cratylus never offers his own account of the 'natural correctness of names' [...] It is Hermogenes who states Cratylus' basic position”, Nightingale 2003, 226.

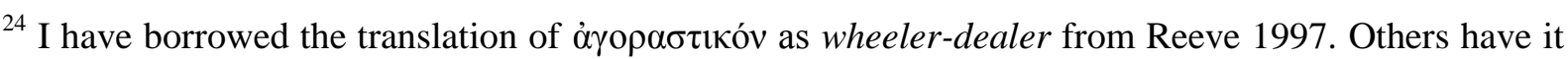
differently: Sallis 1975, 250, has bargainer. I suppose monger, entrepreneur, trader, or peddler would also work. As pointed out by Ewegen 2014, 14, Hermes is the god of the agora, a word that of course

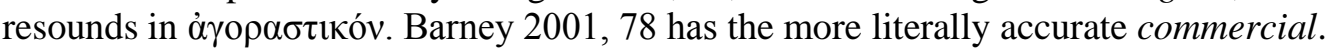


explain, however, he does not. In contrast to Hermogenes' rich brother Callias, famous from the Protagoras, Hermogenes is not in control of his inheritance (391c2).

Although this joke undeniably trades on Hermogenes' lack of money, it also makes another, more subtle, point. There is something absurd about the jokes' presuppositions. Beside the fact that the name itself would not have been able to pick out Hermogenes as an individual even if he would have been a good wheeler-dealer, ${ }^{25}$ it is also clear that both Socrates and Cratylus manage to understand who they are talking about. In this light, the absurdity shines forth. Hermogenes' name does not contain sufficient descriptive information in itself to pick him out, yet they both know who they are talking about. It is absurd, then, to think, as Cratylus' joke presupposes, that the value or correctness of a name can be appreciated independent of its use.

Accordingly, Socrates' account of Cratylus' joke makes two points. On the one hand, it shows that in actual practice is it absurd to think that Hermogenes' name is correct only if he can display the characteristics that his name could be said to describe. On the other hand, it also shows that if Cratylus' joke is to make sense, it must be presupposed that a name is a self-sustained and independent commodity, in the sense that its value, as a name, is userindependent. On this account, and just as any commodity, a name is assumed to be able to change hands without any loss of content or meaning. When Socrates observes that one of the distinguishing characteristics of language is its commercial ( $\dot{\alpha} \gamma o \rho \alpha \sigma \tau \imath \kappa o ́ v)$ nature, it is supposedly something like this he has in mind. Language, evidenced by Cratylus' position and joke, is not resilient enough to resist the commodification of its names. However absurd a closer inspection may make it seem, this is nothing out of the ordinary. We often think that names or words can maintain their meaning and value independent of the different situations they are to function in. But this, of course, does not make it true. And there are several reasons to think that Socrates' introductory conversation with Hermogenes offers an alternative account and a different model of explanation.

Culminating at around 390c3, Socrates suggests that the natural correctness of the names must be judged in terms of use. As we shall see, this means that neither the idea of an independent capacity to encapsulate descriptive content nor the idea that the names have the power to refer to ultimate reality are sufficient, or even necessary, explanations of what it means for a name to be correct. Instead, it is the name's ability to function in its specific

\footnotetext{
${ }^{25}$ So Gonzales 1998, 71.
} 
context that decides its correctness, because it is only the users of the names that can determine their aptitude.

Socrates' argument to this end sets out as a refutation of the conventionalist position ascribed to Hermogenes. ${ }^{26}$ Based on the assumption "that as things seem to each, so they also are" $^{, 27}$ this Protagorean view contends that the correctness of a name is whatever each individual person says it is: "whatever name one gives to a thing is its right name" (384d2-3).

In order to show that this cannot be the case, Socrates starts in the familiar and asks if Hermogenes thinks that there are good and bad people. Hermogenes answers that he certainly does. "And", Socrates goes on, "are the very good very wise and the very bad very foolish?" (386b10-12). Again Hermogenes agrees. This, Socrates concludes, is enough; because insofar as it is unlikely that all men share the same believes, one cannot at the same time think that things are to each as they seem, and that some have it wrong (386d2-6). Instead, Socrates suggest, Hermogenes' consent has other implications. If one is to maintain that there are both wise and ignorant people, one must also accept that "things ( $\tau \grave{\alpha} \pi \rho \alpha ́ \gamma \mu \alpha \tau \alpha)$ have some stable

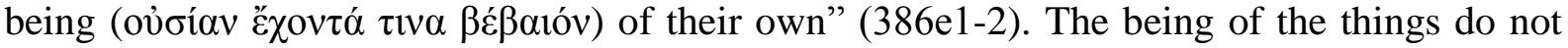
depend on us, "nor [are they] caused by us" (386e2). As Hermogenes agrees also to this, Socrates goes on to apply this principle to three cases: action, speaking and naming. Just as the things, Socrates argues, each action has its own stable being. And since speech is a part of action, and naming a part of speech, the principle also applies to naming. ${ }^{28}$ The act of naming or name-use (not to be confused with name-making) is not to each what they find fit. Instead, it has its own distinct nature.

With this established, Socrates is ready to spell out the consequences: As it comes to naming, it is reasonable that we "name things in a natural way for them to be named and with what is natural for naming them" (387d4-5). Hermogenes cannot but agree, and Socrates goes on to investigate to what this natural use of the names amounts. Socrates argues by analogy. Just as in cutting and burning, he suggests, naming is performed with a tool (ôpyavov, e.g. 388a8). Just as one needs the proper instrument for cutting when one is to cut, one will need a

\footnotetext{
${ }^{26}$ Barney 1997 correctly argues that Hermogenes' actual position is much more reasonable and commonsensical than the position Socrates actually comes to refute. See also Smith 2014.

${ }^{27}$ McKenzie 1986, 129. My argument, just as McKenzie's, requires that 385b-c is in the right place in the text. This has been disputed by Schofield 1972. On Hermogenes' Protagorean point of view, see Sallis 1975, 196.

${ }^{28}$ Cf. Soph.261d-262e where the fallacy of ascribing the features of the whole to the parts is elucidated. For discussion, see Sallis 1975, 195 n10 or Luce, J.V, 1969, 'Plato on Truth and Falsity in Names' Classical Quarterly 63.
} 
name to name. In order specify what this entails, Socrates begins by focusing on the tool. In analogy with the instruments for cutting and burning and insofar as any tool is what it is to be

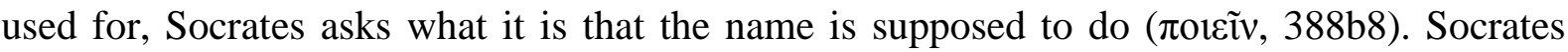
answers by the use of another analogy. Just as a shuttle is a tool for weaving, so is a name a

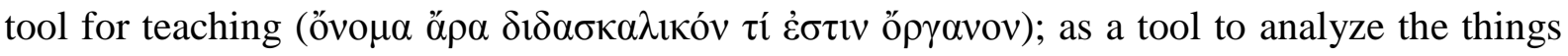

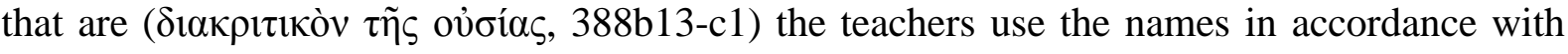
the nature of their practice. ${ }^{29}$ Without, for the moment being, getting into the complicated question of what Socrates means by teaching (I shall return to this below), two things are nevertheless clear. ${ }^{30} \mathrm{~A}$ name has a practical function and its natural correctness should be judged in terms of its ability to perform this function.

Socrates' ensuing argument also confirms these points. In order to establish a distinction between the name-users and what we have come to know as the name-makers,

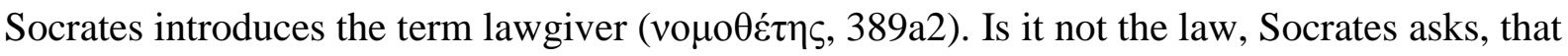
gives us the names? ${ }^{31}$ Confirmed by Hermogenes consent, Socrates goes on to ask how the specific action of the lawgivers is supposed to be performed. Again, Socrates answers by analogy. Just as the carpenters make the shuttles to be used in weaving, so do the lawmakers make the names to be used in naming. And just as in the case of the shuttles, the names must be made in accordance with the function that they are supposed to have in each specific context.

[I]t seems that there is a form of shuttle that is naturally suited to each type of weaving. And the same holds of tools in general (389d1-2).

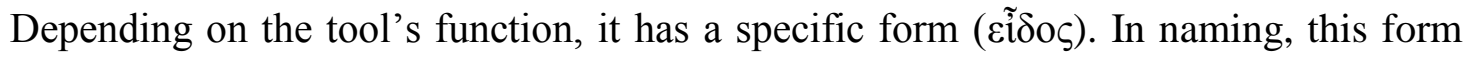
corresponds to the individual name's specific function; and it is in terms of this function-form that the name-makers' ability must be judged.

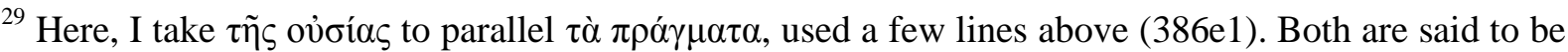
stable, but none of them are used in any stronger technical sense. Presumably, Socrates is not talking about the Forms. As the examples of cutting, burning and weaving make clear, the stability at stake is not exclusive to superhuman reality. For the view that Socrates has a different priority and that he wants to say that the real function of the names is to describe ultimate reality and that teaching is subordinate to this function, see Sallis 1974, esp.208. Cf. also Sedley 2003, 61-66; Trivigno 2012, esp.70.

${ }^{30}$ To anticipate, I shall argue that teaching is what the dialecticians do. Yet, since the dialecticians do not have privileged access to ultimate reality, dialectical teaching does not equate with informationsharing.

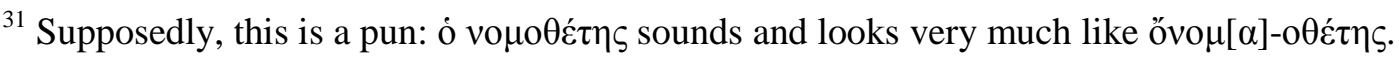


On this basis, then, you will judge the lawgiver [or name-maker], whether he be here or in

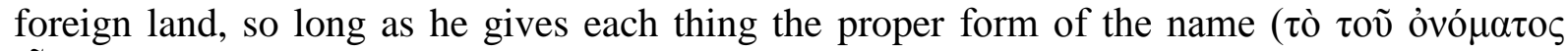

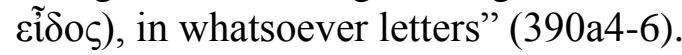

As we saw above, it was these passages that led Sedley to introduce the concept of the name-Form. In order to encompass the claim that a naturally correct name is soundindependent ("here or in foreign land"32), yet established in accordance with a Form, he saw it necessary to introduce a mediating notion that could explain how the names identify the real things. With some important reservations, Trivigno endorsed a similar account in arguing that even if it is not the sounds that carry the load, Socrates considers the names naturally correct insofar as they manifest a stable link to the Form they refer to.

But judging by how Socrates explains what the form in this context is, it does not seem necessary to make such an interpretative move. Another explanation that does not invoke the technical notion of the Form may seem to make more sense. Indeed, when Socrates at the very end of the dialogue explicitly discusses the Forms (at 439b4-440e7), he makes it perfectly clear that knowledge of the Forms is not accessible through names. Thus, insofar as form in this context is understood as Form, this would mean that it would be impossible for any name-user, without prior knowledge of the Forms, to know if the names they are using, and the name-Forms this depends on, are correct. ${ }^{33}$ Socrates' ensuing account of how the name-makers' work must be judged and superintended by the name-users also encourages a different explanatory model. Because even if Socrates does suggest that the art of namemaking aims at making names that pick out the things ("so long as he gives each thing the proper form of the name"), this ambition cannot determine their natural correctness. This, instead, is determined in practice and by the names' ability to perform their function. Again, Socrates argues by analogy.

Now who is likely to know whether the proper form ( embodied in any piece of wood? The carpenter who made it (ó $\pi$ oví $\sigma \alpha \varsigma$, ó $\tau \dot{\varepsilon} \kappa \tau \omega \nu$ ) or the

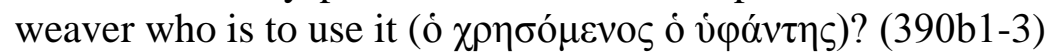

Hermogenes answers that it is "the one who is to use it". It is the user that should judge whether a name is correct or not, and not the maker. Without contradicting Hermogenes, Socrates also goes on to spell out what this entails. In order to make the names

\footnotetext{
${ }^{32}$ As we have seen, Socrates also emphasizes the fact that it does not "matter whether the same thing is signified by the same syllable or by different ones. If a letter is added or subtracted, that doesn't matter either, so long as the being of the thing is in control and is expressed in its name" (393d1-4).

${ }^{33}$ Cf. Gonzalez 1998, 68-69.
} 
in accordance with the forms, the name-makers need to adapt their creations to the user ("o $\chi \rho \eta \sigma o ́ \mu \varepsilon v o \varsigma ", 390 \mathrm{~b} 2-3)$. Here it is important to keep in mind that name-making is described as a fallible endeavor. As we shall see in some detail later down the line, and even if Socrates suggests that there is a realm of divine names, the names Socrates is talking about are made for human use. Indeed, judging from the fact that Socrates insists that the name-makers need to be supervised, he apparently does not consider name-making a divine affair. Even if each name ideally is informed by the function-form it is supposes to perform, this cannot be taken for granted. Instead, the names must be evaluated in actual practice by someone with the proper skill. Accordingly, it is also reasonable to assume that the natural correctness of the names is undetermined until they are put to use.

In the case of shuttles, for example, the weaver may discriminate the worst exemplars by sight alone, but as it comes to the subtleties, the tool must be put to the trial of use. It is the user and not the maker that is the proper judge. And as such, their judgment is also contextdependent. Depending on who is to use the name and where, it must be reevaluated. Just as a shuttle, the name must fit the situation where it is to be employed; otherwise it will not make sense. Supposedly, it is for this reason that Socrates says that the sounds and letters do not matter (393d1-4). Of course they matter, but only insofar as they are chosen with care to function in the given context. It is only in this way that a name can be said to make things manifest or clear (e.g. 393d4: $\delta \eta \dot{\lambda} \omega v$ ). If properly used, a name may be able to communicate what its user wants it to communicate. But this depends on the name's ability to perform its specific function. Presumably, this is why Socrates articulates the name-maker analogy as he does: The carpenters, i.e. the name-makers, must have the function of weaving, i.e. nameusing, in "in view" ( $\beta \lambda \varepsilon \dot{\pi} \omega v, 389 \mathrm{a} 7)$ when they make the shuttles, i.e. the names.

As this seems to suggest, then, there is no need to explain the notion of the form by appealing to the Form, except insofar as Plato always has use and function in mind when he talks about them. In referring to Socrates' shuttle analogy, Francisco Gonzalez draws a similar conclusion: "[T]his analogy is of extreme importance in showing that the nature of a name is to be found in its use" $(1998,68)$. Insofar as Gonzales is right, as I think he is, this has two implications. First, it means that the natural correctness of the names is not a matter of the names' ability to encapsulate descriptive contents in their sounds and letters. ${ }^{34}$ Second,

\footnotetext{
${ }^{34}$ If the names are not confined or defined by their material constituents each should be able to have many meanings and many the same. This is also what Socrates suggests. There are two telling examples: (a) knowledge and (b) king. (a) Substantiated in terms of his two etymologies of the name

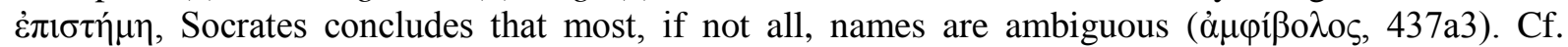
Trivigno 2012, 62. (b) Just after 394a, Socrates points out that even if two potions ( $\varphi \alpha ́ \rho \mu \alpha \kappa \alpha, 394 a 7$ )
} 
it also means that the natural correctness of the names is not determined by their inherent or independent ability to refer to some transcendent reality. The names, it seems, are not to be understood as independent and self-sustained entities at all. A name can certainly have a referent and refer to some specific phenomena (even if it cannot encapsulate it), but this capacity of referring is not contained in the name itself, but in its use and function.

\section{(ii) Origin and Theft}

The second characteristic that Socrates' etymology of the name Hermes associates

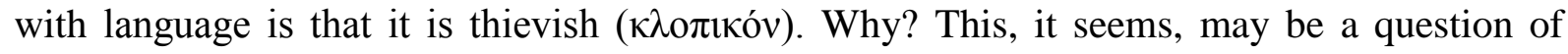
origin. As we have seen, Socrates' etymology of his name suggests that Hermes is the contriver of speech and language and here, it seems, we face to two alternatives. Either Hermes is the originator of the language of the gods or he is the creator of human language and thus to be identified with the lawgivers, or both. As one commentator has pointed out though, since the language of the gods contains no falsehood, it may seem more likely that "Hermes, with his propensity to theft and deceit, is mythically identified with the original lawgiver who instituted human speech" (Sallis 1975, 253). ${ }^{35}$ The truth of such a mythical identification cannot perhaps be ultimately settled, but it is nevertheless possible to draw one reasonable conclusion. Even if the origin of divine language is unclear, ours is not: Human language was contrived by a thief and it inherited its contriver's characteristic. ${ }^{36}$ But what, then, are we to make of this?

As has been persuasively argued by Andrea Nightingale (2003), one of the most important messages that the Cratylus is meant to deliver is that human language has a propensity for theft. ${ }^{37}$ Evidenced by how Cratylus steals Socrates' words in articulating his naturalist position, and by how Socrates' traces his own words back to an external origin, Nightingale shows the way in which the Cratylus dramatizes the notion of language with

can have different appearances, a true doctor can see that they have the same powers. The same goes for names: "[In] Astyanax and Hector, none of the letters is the same, except t, but nevertheless they have the same meaning. And what letters has Archepolis (ruler of the city) in common with them? Yet it means the same thing; and there are many other names which mean simply king" (493b6-c4).

${ }^{35}$ So also Ewegen 2014, 40.

${ }^{36}$ On Hermes as the god of thieves, see Brown, N.O, 2012, Hermes The Thief: The Evolution of A Myth, Literary Licensing.

${ }^{37}$ Nightingale uses the terms 'borrow', but I think 'steal' and 'theft' is more on target, since there is no consent involved. 
which it operates $(2003,235)$. As such, Nightingale's account does not only cast serious doubt on the assumption that Plato ultimately believes that human language has an original and genuine source at all (as Sedley has it). It also offers further reasons to reconsider the appeal of the discursive optimism shared by Sedley and Trivigno. But in order to see how this works, let us first take a closer look at what Nightingale has to say about the origin of Socrates' and Cratylus' words, beginning with former.

One passage that plays an important role in Nightingale's argument is $413 \mathrm{~d} 7-8$. Here, Socrates does not only claim that his words are not his own, he also warns of their deceptive force. "Perhaps I may deceive ( $\dot{\varepsilon} \xi \alpha \pi \alpha \tau \eta \dot{\sigma} \alpha \mu \iota)$ you", he says, "into thinking that all I am going to say is my own". Insofar as Socrates is to be trusted, there are reasons to be suspicious of the origin of his words. It may be the case that the point of view he voices is not his own.

To any reader of a Platonic dialogue where Socrates is the main speaker, this should come as no surprise. What may be more surprising is the extent to which the Cratylus is permeated with this type of thievish argumentation.

Socrates' affirmative reply to Hermogenes' suggestion that Socrates, in the course of his etymological investigations, may be "uttering oracles $(\chi \rho \eta \sigma \mu \omega \delta \varepsilon \tilde{v})$, exactly like an inspired ( $\dot{\varepsilon} \vee \theta o v \sigma ı \tilde{\omega} v \tau \varepsilon \zeta)$ prophet”, is telling:

Yes, Hermogenes, and I am convinced that the inspiration came to me from Euthyphro the Prospaltian. For I was with him and listening to him a long time early this morning. So he

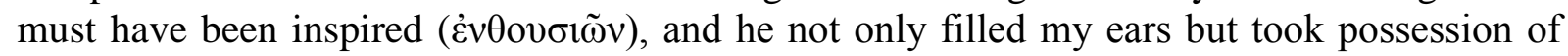

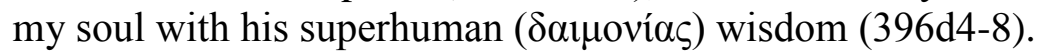

Not only does Socrates here affirm that he is uttering oracles like an inspired prophet. He also locates the source of this inspiration in Euthyphro, who himself is inspired. And even if Socrates leaves the source of Euthyphro's inspiration in the shadows, there are certainly reasons to be suspicious about what is going on here. Indeed, Socrates is quite suspicious of the performance himself:

So I think this is our duty: we ought today to make use of this wisdom [i.e. the inspiration] and finish the investigation of names, but tomorrow, if the rest of you agree, we will conjure it away and purify ourselves, when we have found someone, whether priest or sophist, who is skilled in that kind of purifying (396d8-397a1).

As Nightingale suggests, Socrates' claim that his soul has been possessed by Euthyphro is "deeply ironic" and "Socrates is not endorsing the discourse that he is borrowing and reproducing" (2003, 232). In line with its Hermogenic origin, Socrates is instead articulating a view that he has stolen from someone else. All of his attempts to uncover the 
genuine properties of the names, are based on a view that is not his own. The Heracleitian tendency of Socrates' etymologies is no less proof of this than his explicit claim that he does not even believe himself.

My excellent Cratylus, I myself have been marveling $(\theta \alpha v \mu \alpha \dot{\zeta} \omega)$ at my own wisdom ( $\tau \grave{\eta} v$ $\dot{\varepsilon} \mu \alpha v \tau o \tilde{v}$ бoфíav) all along, and I cannot believe in it $(\dot{\alpha} \pi \imath \sigma \tau \tilde{\omega})$. So I think we ought to reexamine my utterances. For to deceive oneself is the worst of all deceptions (

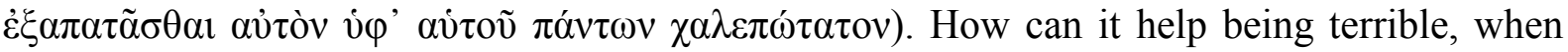
the deceiver (ó $\dot{\varepsilon} \xi \alpha \pi \alpha \tau \eta \dot{\sigma} \sigma \omega v$ ) is always present and never stirs from the spot? So I think we must turn back repeatedly to what we have said and must try, as the poet says, to look "both forwards and backwards" (428d1-8). ${ }^{38}$

As M. M. Mackenzie $(1986,128)$ has rightly pointed out, this quotation from Homer (Ill.1.343; 3.109) bids Plato's readers to look at the dialogue as a whole; both backwards and forwards. It asks us to pay close attention to the positions at stake. For even if Socrates' distanced attitude signals that the words he is articulating are not his own, Cratylus does not seem to understand the layering of this double position. He does not see Socrates' evasiveness. Instead he is deeply impressed:

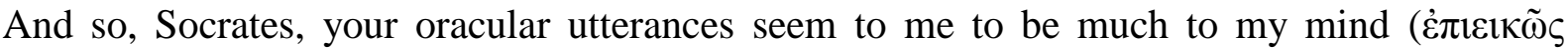

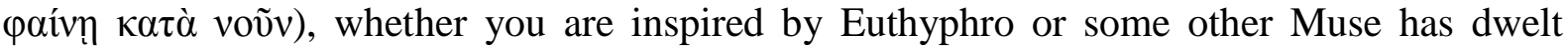
within you all along without our knowing it (428c5-7).

However ironic it may seem, Cratylus' is no better himself and when he here near the end of the dialogue finally begins to talk, it become clear that also his position is stolen. It all starts to unravel at $429 \mathrm{~b} 12$ where Socrates sets out to interrogate Cratylus. Socrates wants to examine if Cratylus agrees to the naturalist theory of names that Socrates so-far has been propounding, and to reach this end he again asks the question that initiated the dialogue: How about the name Hermogenes, "shall we say that it is not his name at all, unless he belongs to the race of Hermes, or that it is his name, but is incorrect?" (429b12-c2). I think, Cratylus answers, that it is not his name at all (429c3-5).

There are three statements in connection to Socrates' (re)examination of this answer that are telling: First, at 429a1, Cratylus claims that the original name-makers were lawgivers $(\operatorname{vo\mu } \theta \dot{\varepsilon} \tau \alpha \mathrm{l})$. As we have seen, this is a notion that Socrates introduced at 389a2 to fill a certain specific function. Cratylus does not make any comments about this, but swallows the

\footnotetext{
${ }^{38}$ This point is also repeated at 391a4-6: "I, my dear Hermogenes, do not say that there is any [natural correctness of names]. You forget what I said a while ago, that I did not know, but would join you in examining [the matter]" and at 428a6-8: "For that matter, Cratylus, I would not positively affirm any of the things I have said. I merely expressed the opinions which I reached with the help of Hermogenes".
} 
notion whole and reuses it without hesitation. Second, at 434d9-13, Cratylus repeats Socrates' claim from 414c4-d6, where he argued that the etymological science may sometimes need to add or remove letters in order to get at the original construction - a trick that Socrates then however immediately claimed would result in the fact that "we would be able to fit every word to every thing" $(414 d 7-9) .{ }^{39}$ Third, at $435 \mathrm{~d} 4$, Cratylus claims that the function of the names is to teach ( $\delta 1 \delta \alpha ́ \sigma \kappa \varepsilon v v)$, a function that Socrates introduced at $388 \mathrm{~b} 13$ in order to argue that the natural correctness of a name is to be understood in terms of its use.

In the light of these passages, Nightingale concludes that "[Cratylus'] language seems in some way not to be "in himself". Cratylus voice is not his own and "[t]he most obvious illustration of this notion is the fact that his views are put in the mouth of Socrates, who, in turn, ascribes them to Euthyphro" (2003, 231). But why, then, Nightingale goes on, did Socrates not prevent this from the beginning? Why did he not make Cratylus state his own case at the outset? As we know from other dialogues, this would not be unsocratic behavior.

Nightingale's explanation is as important as it is telling. What Socrates is doing is that he "mimics and mocks Cratylus' evasiveness". In order to illustrate "the dangers of borrowed [or stolen] words" $(2003,233)$ Socrates lets the show go on. Not only does he allow Cratylus to go on as an echo, to a large extent he also becomes such an echo himself. According to Nightingale, this conduct is supposed to function as warning. Similar to Socrates' account of the dangers of alien voices in the Phaedrus, the reader is supposed to experience the consequences of a discourse solely inhabited by the voices of strangers. Instead of being staged as a friendly conversation between persons with views that transpire from reason and their own serious considerations of the matters under discussion, the Cratylus is a play with “ideas and words of others" $(2003,235)$.

When Plato makes Socrates say that one of the central characteristics of language is its thievish nature, it is presumably something like this he has in mind. In contrast to what we could imagine as a philosophical ideal, where all of our thoughts and words emerge from reason and rational deliberation, human language cannot guarantee such an etiology. In and of itself, it cannot guarantee a genuine and true source. Socrates' distinction at 408c5-8 between the language of the gods and the language of humans also confirms and expands this point. Not only does Socrates explicitly argue that divine language, in contrast to human, is always true. As we shall now see in some detail, he also claims that this makes our situation rather tragic.

\footnotetext{
${ }^{39}$ Trivigno's translation.
} 
(iii) Deception and Dialectic

This brings us to the third characteristic that Socrates associates with the power of

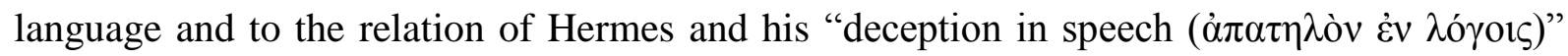

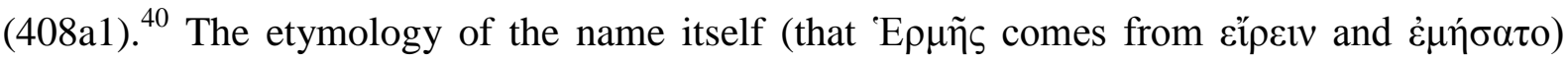
contains no further information that may explain this characterization. But Socrates' subsequent remarks about the name of a related god do.

Pan (Пóv), Socrates explains, is the son of Hermes. And Pan, is "either speech ( $\lambda$ ó $\gamma \circ \varsigma)$ or the brother of speech", for "that brother resembles brother is not at all surprising" (408d24). As such, Socrates goes on, we are not only dealing with everything ( $\tau$ ò $\pi \tilde{\alpha} v$ ), because language or speech means everything ("ó $\lambda o ́ \gamma o \varsigma ~ \tau o ̀ ~ \pi \tilde{\alpha} \nu \sigma \eta \mu \alpha i v \varepsilon l ”)$, this is also a twofold

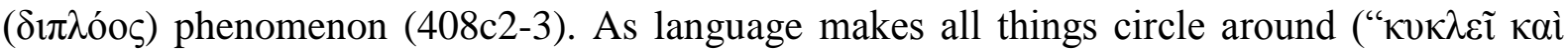

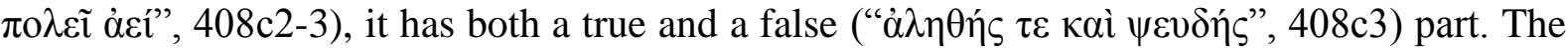

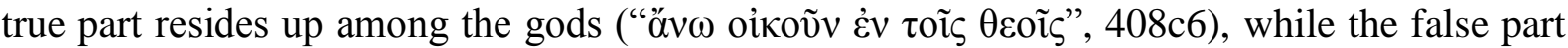

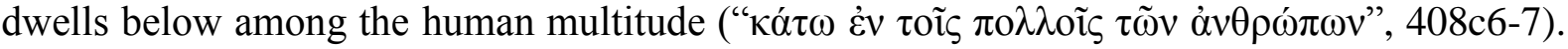

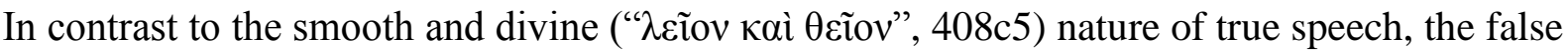

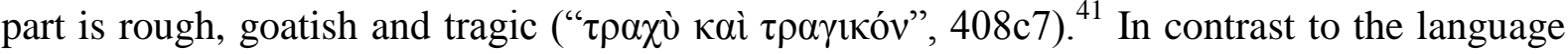

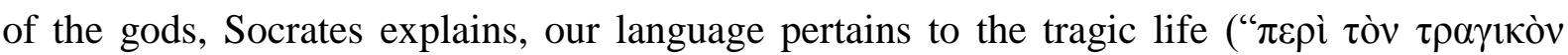

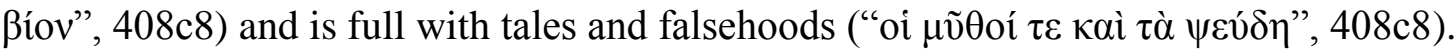

Socrates justifies these claims and the distinction between divine and human language by reference to Pan and the etymology of his name. Pan or the personified all ("ó $\pi \tilde{\alpha} v$ "), just

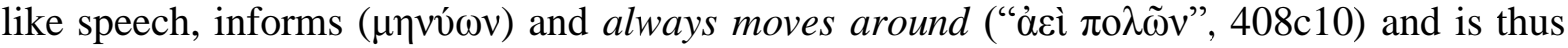

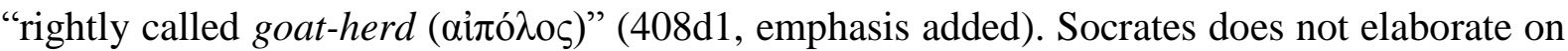
how this sound-similarity can justify the analogy, but he is nevertheless not reluctant to

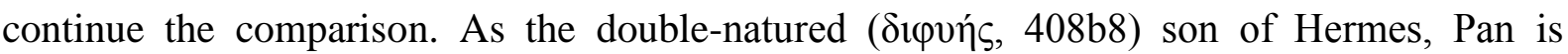

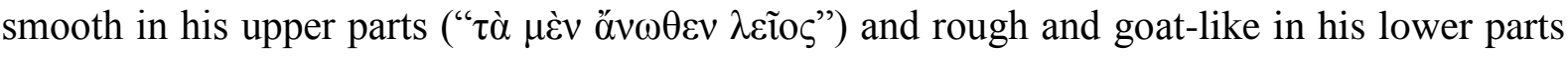

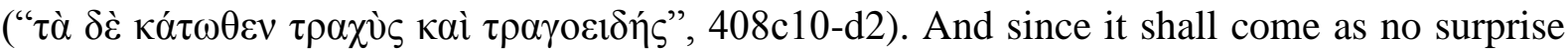
that brother resemble brother, Socrates' distinction between the true language of the gods and the deceptive and tragic language of humans, may seem to be vindicated.

\footnotetext{
40 "Would it $[\ldots]$ be possible that in examining the name 'Hermes' we are being deceived about the deceptive power of [language]? Clearly not, for then we would be in the impossible situation of being deceived by [language] into thinking that deception on the part of [language] is impossible", Sallis 1975, 252.

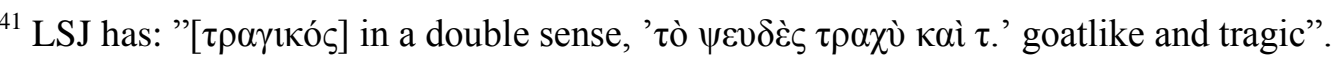


Even if a reader may not be fully satisfied with this explanation, it makes its point. Because, as it seems reasonable to believe, it is in the light of the distinction here established

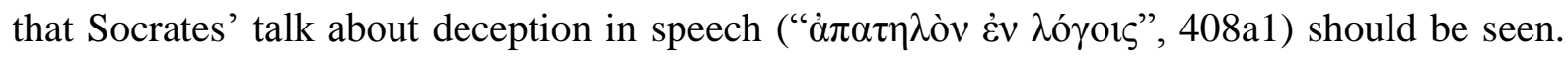
As Rachel Barney $(2001,79)$ has perceptively pointed out, human language is permeated by the possibility of deceptions and misunderstandings, because we "mistake one kind of language for the other, since both kinds look alike". Supposedly, it is also this that makes our situation tragic. For us it seems as if both kinds of speech, both the rough and the smooth, do the same things: they both inform about everything and make this information circle around. But humanity has no access to the realm above. We only have lies and myths. "As a result", Barney goes on, "we habitually mistake the lower discourse for the higher, and take its objects to be the true realities" $(2001,79)$. Without the ability to see the bigger picture, we are caught in the web of our own words. And since these words give the appearance of being similar to the words of the gods, we are blinded by their deceptive light. Not only do we believe that our language, like the language of the gods, can be true and smooth. This mistake also makes our situation rough and tragic. Even if it is doubtful that Plato shares all aspects of our modern notion of tragedy, he does seem to acknowledge the frustration and inevitable failure that it involves.

The idea that the true part of speech is only accessible to the gods is also emphasized as Socrates introduces his etymological enterprise at the outset. In lack of money, and having just explained to Hermogenes that the best information about language and names should be bought from the sophists, Socrates offers a way out. He turns to the free information to be

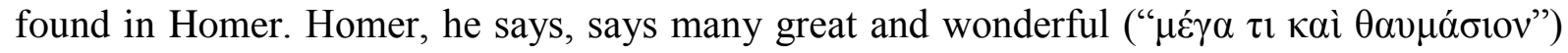
things about language and the correctness of names (391d6), and he often distinguishes between how humans and gods talk: In contrast to the names we are using, the names used by

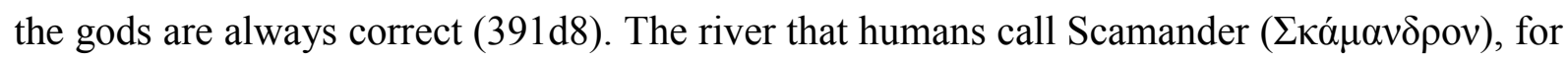
example, should really be called Xanthus ( $\Xi \alpha \dot{v} \theta 0 v)$, and even if we call the bird cymindis ( $\kappa \dot{\mu} \mu v \delta ı)$ ) the correct and divine name is chalcis $(\chi \alpha \lambda \kappa i ́ \delta \alpha)$.

As Socrates sets out on his etymological enterprise he does however leave little room for doubt. The names he is talking about are human. Even if Homer seems to offer the opportunity to investigate the names that the gods are using, Socrates makes it clear that "these things are probably greater than what you and I can discover ( $\dot{\alpha} \lambda \lambda \dot{\alpha} \tau \alpha \tilde{v} \tau \alpha \mu \grave{\varepsilon} v$ ไ $\sigma \omega \varsigma$

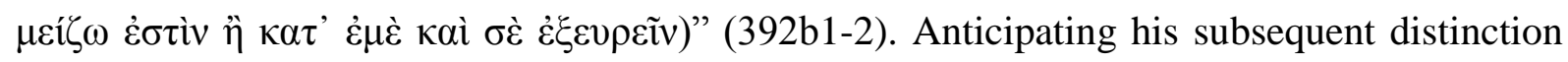
between human and divine language, Socrates' avoids discussing the names made for gods. For even if Homers' language appears to contain "great and wonderful information about the 
correctness of names" (391d6-7), this is not something that Socrates considers to be within his reach. Instead he goes on to look at the names made for men and nothing else.

Insofar as Socrates' distinction between divine and human language has any bearing, this has several consequences. Not only does it imply that the human part of Hermes' offspring has not inherited any of his divine characteristics. It also implies that our human language lacks the capacity to carry hidden divine information. ${ }^{42}$ In line with the human orientation of Socrates' investigation of the names, we are left on our own. As such, this also implies that insofar as we do not properly assess the limited scope of what we can say and do with words, we are caught in a frustrated and tragic situation. Through the false appearance of being an all-encompassing medium for the circulation of information about everything, our language becomes a mirage. It disorients us in the quest for truth, and the deceptive resemblance between our language and that of the gods makes us think that the secrets of reality can be revealed by our names.

As we have seen, there are however scholars that defend a much more optimistic view. Despite Socrates' explicit claim to the opposite effect at 439b4-8 ("how realities are to be learned or discovered is perhaps too great a question for you and me to determine"), Franco Trivigno insists that the Cratylus outlines a comprehensible way in which human language can reveal the truth about reality. "There is a way", as he argues, "in which words are the path to philosophical truth" $(2012,69)$. According to Trivigno, when used in the right way, human language can be used to refer to the real things and this use identifies a superior type of discursive practice called dialectic. Let us take a look at how Trivigno wants this to work.

For the dialecticians, Trivigno insists, "names are subordinate to things" $(2012,70)$ and this ensures a path to ultimate reality. By using the names as if they refer to the real things almost directly, mediated only by the so-called natural names, Trivigno insists that "the dialectical use explicitly aims at and refers to the stable nature[s] in order to attain knowledge of them" (72). Established in a complex process that "involves appealing to each thing's natural name [or name-Form] for guidance" (43), the names in a dialectical conversation have a special status that allows them to be used in such a way that they can communicate substantial and true information about reality.

Besides the fact that Trivigno' arguments do not seem to square with Socrates' critical account of human language contained in the etymology of the name Hermes, we have also seen that there are reason to doubt that Plato endorses the notion of a natural name at all. In

\footnotetext{
${ }^{42}$ Pace Kirkland 2008.
} 
addition, Trivigno's arguments also build on a doubtful assumption in relation to how he conceives of dialectical communication. This assumption has two aspects that both relate to its epistemic standards.

One the one hand, Trivigno suggests that even if the sounds that the dialecticians are using are arbitrary, the dialecticians' knowledge of the name-Forms and the form-Forms to which the name-Forms refer endows them with the power to avoid deception and ambiguity. This, however, presupposes that the dialecticians already know what they, according to Trivigno, are supposed to be looking for (72). In this way, Trivigno entangles Socrates in an inverted sort of Meno-like paradox: Why would anyone that already knows of what reality consists have any interests in research? When it comes to the task of the etymologists, we have seen that Trivigno argues that their endeavors to decode the names would be "superfluous" (42) insofar as a proper evaluation of the information thus acquired requires prior and independent knowledge of the things. I see no reasons for why dialectic, on Trivigno's account, would not be superfluous for the same reasons.

On the other hand, Plato never writes that the dialecticians already know what they are looking for. What Plato writes about the dialecticians in the Cratylus is that they know how to

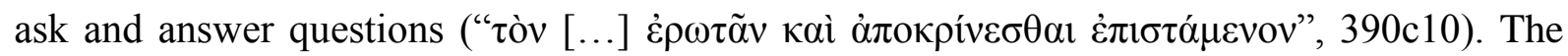
dialecticians are not introduced to exemplify what a person with authoritative knowledge would say, but they are rather discussed as persons that have the skill to use the names in a proper way. ${ }^{43}$ Insofar as this includes, but is not limited to, the ability of asking and answering questions in an attentive and considerate way, this implies that the art of dialectic is conditioned both by the ability to search together ( $\sigma 0 \zeta \eta \tau \varepsilon \mathrm{iv}, 384 \mathrm{c} 2)$ and by what Socrates characterizes as the skill of "investigating things along with you ( $\sigma \kappa \varepsilon \psi o i ́ \mu \eta \nu ~ \mu \varepsilon \tau \grave{~} \sigma o \tilde{)})$ " (391a6). Even if this does not rule out more complex methods and principles - including, for example, the search for essences and definitions - the basics need to be established first. The skill of the dialecticians is never a matter of filling the ones they are teaching with information, but to establish a sufficient level of discursive transparency and, if possible, to advance from there. $^{44}$

\footnotetext{
${ }^{43}$ So Kirkland 2008, 11.

${ }^{44}$ As is well known, stylometrically the Cratylus is an early dialogue, and even if the implications of this are controversial, it does say something. Dialectic in the Cratylus seems to be closer to what is outlined in the Apology than to what is discussed in the so-called later dialogues where it becomes a more and more technical notion. As Socrates suggests in the Apology (38a2-3), there is a sense in which the practice itself carries the value, independently of its possible results. For discussion of the
} 


\section{Conclusion}

Plato's Cratylus is a deceptive dialogue. Not only does Socrates' evasive behavior make it seem more dogmatic than it is. Its proleptic design has also led many commentators to argue that its main objective is to offer an account of how language can be used to capture reality. As we have seen, there are however many passages that reveal a different purpose. Besides Socrates' explicit argument to this effect, at the dialogue's end, the commercial, thievish and deceptive nature of human language, made explicit in Socrates' etymological account of the name Hermes, also implies, in contrary to what is often assumed, that the relation between human language and reality cannot be exhausted neither in terms of encapsulation nor in terms of reference. In addition, a closer analysis of these characteristics has also revealed that one of the dialogue's principle goals is to expose the tragedy of thinking that it can. Consequentially, we have also seen that there are good reasons to dispute three suppositions that sanction this belief: (i) that the natural correctness of the names involves the notion of a natural name or a name-Form, (ii) that the names can correlate to a transcendental source of knowledge and (iii) that the dialecticians have an exclusive knowledge of ultimate reality. Not only does Socrates' identification of the commercial aspect of human language undermine the view that the names are independent and self-sufficient entities. In addition to the functionalistic notion of names and naming offered in its place, Socrates' account of the thievish and deceptive nature of human language also shows that even if we can talk about what is grasped by a human mind and to this extent make ourselves understood, the language we are bound to use is always full of myths and lies and it is essentially disconnected from the reality of the truly existing things.

Olof Pettersson

University of Bergen 


\section{Bibliography}

Anagnostopoulos, G. 1972. 'Plato's Cratylus: The Two Theories of the Correctness of Names' Review of Metaphysics 25 (4): 691-736.

Ademollo, F. 2011. The Cratylus of Plato: A Commentary. Cambridge: Cambridge University Press.

Arieti, J.A. 1991. Interpreting Plato: The Dialogues as Drama. Savage (Maryland): Rowman \& Littlefield.

Barney, R. 2001. Names and Nature in Plato's Cratylus. New York and London: Routledge.

Barney, R. 1998. 'Socrates Agonistes: the Case of the Cratylus Etymologies' Oxford Studies in Ancient Philosophy 16: 63-98.

Barney, R. 1997. 'Plato on conventionalism' Phronesis 42 (2): 143-162.

Baxter, T. 1992. The Cratylus: Plato's Critique of Naming. Leiden, New York, Köln: Brill.

Benardete, S. 1980. 'Physics and Tragedy: On Plato's Cratylus' Ancient Philosophy 1: 127140.

Brock, R. 1990. 'Plato and Comedy' 39-49 in E.M. Craik ed. Owls to Athens: Essays on Classical Subjects Presented to Sir Kenneth Dover. Oxford: Clarendon Press.

Brown, N.O. 2012. Hermes The Thief: The Evolution Of A Myth, Literary Licensing.

Ewegen, M. 2013. Plato's Cratylus: The Comedy of Language. Indiana University Press.

Findlay, J.N. 1973. Plato: The Written and Unwritten Doctrines. New York: Humanities Press.

Fowler, H.N. 1921. Translation of the Cratylus in Plato in Twelve Volumes. Vol.12. Cambridge, MA: Harvard University Press. London: William Heinemann Ltd.

Goldschmidt, V. 1940. Essai sur le Cratyle: contribution à l'histoire de la pensée de Platon. Paris: Librairie Ancienne Honoré Champion.

Gonzalez, F.J. 1998. Dialectic and Dialogue: Plato's Practice of Philosophical Inquiry. Evanston: Northwestern University Press.

Grote, G. 1867. Plato and the Other Companions of Socrates. Vol. 2. London: J. Murray.

Ketchum, R.J. 1979. 'Names, Forms and Conventionalism: Cratylus, 383-395' Phronesis 24 (2):133-147.

Kirkland, S. D. 2007. 'Logos as the Message From the Gods: On the Etymology of Hermes in Plato's Cratylus' Bochumer Philosophisches Jahrbuch Fur Antike Und Mittelalter 12 (1): 114.

Kretzmann, N. 1971. 'Plato on the Correctness of Names' American Philosophical Quarterly 8 (2): 126-138.

Luce, J.V. 1969. 'Plato on Truth and Falsity in Names' Classical Quarterly 63: 222-33.

Luce, J.V. 1964. 'The Date of the Cratylus' The American Journal of Philology 85(2): 136154.

Nightingale, A. 2003. 'Subtext and Subterfuge in Plato's Cratylus' 223-240 in A.N. Michelini ed. Plato as Author: The Rhetoric of Philosophy. Leiden: Brill. 
Mackenzie, M.M. 1986. 'Putting the Cratylus in its Place' Classical Quarterly 36 (1): 124150 .

Riley, M.W. 2005. Plato's Cratylus: Argument, Form, and Structure. Amsterdam: Rodopi B.V.

Reeve, C.D.C. 1997. Translation of Plato's Cratylus in Cooper ed. Plato: Complete Works. Indianapolis: Hackett.

Sallis, J. 1996. Being and Logos: Reading the Platonic Dialogues. 3rd edn. Bloomington: Indiana University Press.

Schofield, M, 1972. 'A Displacement in the Text of the Cratylus' Classical Quarterly 22 (2): 246-253.

Sedley, D. 2007. 'Plato on Language' in H. H. Benson ed. A Companion to Plato. Malden, MA: Blackwell Publishing Ltd.

Sedley, D. 1998. 'The Etymologies in Plato's Cratylus' Journal of Hellenic Studies 118: 140154.

Sedley, D. 2003. Plato's Cratylus. New York: Cambridge University Press.

Silverman, A. 2001. 'The End of the Cratylus' Ancient Philosophy 21 (1): 25-43.

Schofield, M. 1972. 'A Displacement in the text of the Cratylus' Classical Quarterly 22, 2465 .

Smith, I. 2014. 'Taking the Tool Analogy Seriously: Forms and Naming in the Cratylus' The Cambridge Classical Journal 60, 75-99.

Thomas, J.C. 2008. 'Inquiry Without Names in Plato's Cratylus' Journal of the History of Philosophy 46 (3): 341-364.

Trivigno, F.V. 2012. 'Etymology and the Power of Names in Plato's Cratylus' Ancient Philosophy 32 (1): 35-75.

Weingartner, R. 1970. 'Making Sense of the Cratylus' Phronesis 15: 5-25. 